\title{
Growth and nutrient status of olive plants as influenced by foliar potassium applications
}

\author{
A. Saykhul ${ }^{1}$, C. Chatzissavvidis ${ }^{2 *}$ I. Therios ${ }^{1}$, K. Dimassi ${ }^{1}$, T. Chatzistathis ${ }^{1}$ \\ ${ }^{\text {IS }}$ chool of Agriculture, Aristotle University, Thessaloniki 54124, Greece. ${ }^{2}$ Department of Agricultural Development, Democritus \\ University of Thrace, Orestiada 68200, Greece. "Corresponding author: cchatz@agro.duth.gr
}

\begin{abstract}
Olive (Olea europaea L.) plants were sprayed (one, two or three times) with nutrient solutions containing $\mathrm{KCl}$, $\mathrm{KNO}_{3}$ and $\mathrm{K}_{2} \mathrm{SO}_{4}$ with the same amount of $\mathrm{K}(0,1,2$ and $3 \% \mathrm{w} / \mathrm{v})$. The weight of the plants was unaffected by salt type, number of sprays or $\mathrm{K}$ concentration of salts, whereas the dry matter percentage was significantly increased in the plants treated with $\mathrm{K}_{2} \mathrm{SO}_{4}$. Furthermore, the application of $\mathrm{K}_{2} \mathrm{SO}_{4}$ led to a significantly higher $\mathrm{N}$ concentration in leaves than that of $\mathrm{KCl}$. K-salts increased $\mathrm{K}$ concentration in plants in the following order: $\mathrm{KCl}>\mathrm{KNO}_{3}>\mathrm{K}_{2} \mathrm{SO}_{4}$ and three foliar applications were significantly more efficient than one. Moreover, irrespective of plant part, $\mathrm{K}$ spray application frequency significantly affected $\mathrm{Fe}$ and $\mathrm{Zn}$ concentrations in the plants studied. Finally, although $\mathrm{KCl}$ increased $\mathrm{Cl}$ concentrations more than $\mathrm{KNO}_{3}$ and $\mathrm{K}_{2} \mathrm{SO}_{4}$, the former fertilizer was the most efficient to improve the $\mathrm{K}$ status of the olive cv. Chondrolia Chalkidikis.
\end{abstract}

Keywords: Chondrolia Chalkidikis, fertilizers, Olea europaea L., perlite, pot experiment, sprays

\section{Introduction}

Research on foliar fertilization most probably started in the early 1950s. In the early 1980s studies were conducted on foliar application of fertilizers for selected crops, but the research was limited only to micronutrients in highvalue horticultural crops (Girma et al., 2007). Nutrients applied to the foliage are generally absorbed more rapidly than when applied to the soil. Soil properties have a strong influence on nutrient availability. For instance, clay soils typically have a high K-fixing capacity and thus, often show little response to soil applied $\mathrm{K}$ fertilizers because much of the available $\mathrm{K}$ is quickly fixed to the clay particles (Brady and Weil, 2002). Therefore, $\mathrm{K}$ foliar fertilizer applications are considered as a valid alternative in order to provide nutrients to plants when soil conditions may limit root uptake or during periods of fast growth when nutrient needs may exceed root supply (Swietlik and Faust, 1984; Toscano et al., 2002). In addition, as a rule, fruit trees have a deep rooting system, which limits the efficiency of fertilizers applied to the soil surface (Mengel and Kirkby, 2001). From a practical point of view, $\mathrm{K}$ foliar application is recommended for orchards located in dry lands because of (i) the lower cost of application, and (ii) the lack of moisture in the soil during the growing period that could limit $\mathrm{K}$ uptake. Foliar application provides a fast method to correct nutrient deficiencies in plants which is fast. Moreover, it is a convenient procedure of applying 
highly soluble fertilizers, especially in very small amounts.

Potassium is known to play important role in olive and oil yield (Elloumi et al., 2009). Olive is a species with a high $\mathrm{K}$ requirement due to the high content of $\mathrm{K}$ present in the olive fruit (Fernandez-Escobar, 2004). Potassium deficiencies are common in olive trees, especially those cultivated under dry land conditions on calcareous soils and represent the main nutritional problem in non-irrigated orchards (Restrepo-Diaz et al., 2009).

Several authors have studied the response of different fruit trees to foliar $\mathrm{K}$ fertilization, e.g. Dikmelik et al. (2000) evaluated its effectiveness in olive. In the latter species, there is great variability in leaf $\mathrm{K}$ concentration between 'on' and 'off' years due to crop load. In this case, foliar application in the spring of the 'on' year is an effective way to apply $\mathrm{K}$. Soon after the leaves have been sprayed with $\mathrm{K}$, it is rapidly translocated to the reproductive structures of olive (Fernandez-Escobar et al., 1999), improving vegetative growth and fruit yield. Some studies, however, have reported irregular responses of fruit trees to foliar fertilizer applications (e.g. in apple, Khemira et al., 1999). Factors such as leaf age, salt type and concentrations, number of foliar applications, water stress and nutritional status of the tree may influence foliar $\mathrm{K}$ uptake in fruit trees (Swietlik and Faust, 1984).

For these purposes, the objective of this study was to evaluate the effect and efficiency of foliarly applied $\mathrm{K}$ forms on the growth and nutrient status of the olive cultivar Chondrolia Chalkidikis.

\section{Materials and Methods}

\subsection{Plant material and growth conditions}

One-year-old, uniform, own-rooted olive plants of the significant Greek table olive cultivar 'Chondrolia
Chalkidikis' were planted in three-liter polyethylene bags containing inert perlite medium. The experiment was carried out in a lathhouse situated on the farm of the Aristotle University of Thessaloniki, Greece (latitude $40^{\circ} 53^{\prime} \mathrm{N}$, longitude $22^{\circ} 99^{\prime} \mathrm{E}$ ) and lasted from 15 March to 30 June (108 days) with an average temperature of $30^{\circ} \mathrm{C}$.

\subsection{Treatments}

Olive plants were irrigated every 15 days with $500 \mathrm{ml}$ of $50 \%$ Hoagland solution (minus K), and every two days the plants were irrigated with good quality tap water. Before planning this experiment, the previous year (2009) we run a similar preliminary experiment in order to choose the appropriate chemicals and concentrations for the main experiment. The preliminary results agree with the results reported in our experiment. The experiment was planned by using three K-salts with the same amount of $\mathrm{K}(0,1,2$ and $3 \%)$. The experiment included ten treatments containing the control and three concentrations of $\mathrm{KCl}, \mathrm{KNO}_{3}$ and $\mathrm{K}_{2} \mathrm{SO}_{4}$ salts equivalent to $0,1,2$ and $3 \% \mathrm{~K}$, with twelve plants per salt treatment. The experiment comprised 120 plants in total. The salt treatments are presented in Table 1. About $300 \mathrm{ml}$ of foliar salt solution per twelve plants (4 plants X 3 per time) were used. In order to improve adhesiveness, glycerin $(2 \mathrm{ml} / \mathrm{l})$ was added to the spray solution. Control plants were sprayed with the same amount of deionised water (-salt). Three foliar sprays were applied as follows:

$1^{\text {st }}$ application: 13 days after the initiation of the experiment (27/3/2010). All twelve plants per salt treatment were sprayed.

$2^{\text {nd }}$ application: 38 days after the initiation of the experiment (21/4/2010). Eight of the twelve plants per salt concentration were sprayed.

$3^{\text {rd }}$ application: 63 days after the initiation of the experiment (16/5/2010). Four of the twelve plants per salt concentration were sprayed. 
Table 1. Treatments used in the experiment.

\begin{tabular}{|c|c|c|c|}
\hline $\begin{array}{l}\text { Treatment } \\
\text { concentration } \\
\text { code }\end{array}$ & $\begin{array}{l}\text { Number } \\
\text { of sprays }\end{array}$ & K-salt & $(\% \mathrm{w} / \mathrm{v})$ \\
\hline C-1 & 1 & no K-salt & - \\
\hline $\mathrm{KC} 1-1$ & 1 & $\mathrm{KCl}$ & 2.00 \\
\hline $\mathrm{KC} 2-1$ & 1 & $\mathrm{KCl}$ & 4.00 \\
\hline KC3-1 & 1 & $\mathrm{KCl}$ & 6.00 \\
\hline KN1-1 & 1 & $\mathrm{KNO}_{3}$ & 2.70 \\
\hline KN2-1 & 1 & $\mathrm{KNO}_{3}$ & 5.40 \\
\hline KN3-1 & 1 & $\mathrm{KNO}_{3}$ & 8.10 \\
\hline KS1-1 & 1 & $\mathrm{~K}_{2} \mathrm{SO}_{4}$ & 2.33 \\
\hline KS2-1 & 1 & $\mathrm{~K}_{2} \mathrm{SO}_{4}$ & 4.66 \\
\hline KS3-1 & 1 & $\mathrm{~K}_{2} \mathrm{SO}_{4}$ & 6.99 \\
\hline $\mathrm{C}-2$ & 2 & no K-salt & - \\
\hline $\mathrm{KC} 1-2$ & 2 & $\mathrm{KCl}$ & 2.00 \\
\hline $\mathrm{KC} 2-2$ & 2 & $\mathrm{KCl}$ & 4.00 \\
\hline $\mathrm{KC} 3-2$ & 2 & $\mathrm{KCl}$ & 6.00 \\
\hline KN1-2 & 2 & $\mathrm{KNO}_{3}$ & 2.70 \\
\hline KN2-2 & 2 & $\mathrm{KNO}_{3}$ & 5.40 \\
\hline KN3-2 & 2 & $\mathrm{KNO}_{3}$ & 8.10 \\
\hline $\mathrm{KS} 1-2$ & 2 & $\mathrm{~K}_{2} \mathrm{SO}_{4}$ & 2.33 \\
\hline $\mathrm{KS} 2-2$ & 2 & $\mathrm{~K}_{2} \mathrm{SO}_{4}$ & 4.66 \\
\hline KS3-2 & 2 & $\mathrm{~K}_{2} \mathrm{SO}_{4}$ & 6.99 \\
\hline C-3 & 3 & no K-salt & - \\
\hline $\mathrm{KC} 1-3$ & 3 & $\mathrm{KCl}$ & 2.00 \\
\hline KC2-3 & 3 & $\mathrm{KCl}$ & 4.00 \\
\hline $\mathrm{KC} 3-3$ & 3 & $\mathrm{KCl}$ & 6.00 \\
\hline KN1-3 & 3 & $\mathrm{KNO}_{3}$ & 2.70 \\
\hline KN2-3 & 3 & $\mathrm{KNO}_{3}$ & 5.40 \\
\hline KN3-3 & 3 & $\mathrm{KNO}_{3}$ & 8.10 \\
\hline $\mathrm{KS} 1-3$ & 3 & $\mathrm{~K}_{2} \mathrm{SO}_{4}$ & 2.33 \\
\hline KS2-3 & 3 & $\mathrm{~K}_{2} \mathrm{SO}_{4}$ & 4.66 \\
\hline KS3-3 & 3 & $\mathrm{~K}_{2} \mathrm{SO}_{4}$ & 6.99 \\
\hline
\end{tabular}

\subsection{Plant growth traits and chemical status}

At the termination of the experiment $\left(108^{\text {th }}\right.$ day), plants were harvested and leaves (new and old), stems and roots were separated. The leaves that developed after the treatments started, were considered as new leaves. Plant height and fresh weight (FW) of all plant parts were recorded. Following, all samples were washed twice with deionized water, dried at $75^{\circ} \mathrm{C}$ for $48 \mathrm{~h}$, weighed for dry matter weight (DW) and then ground to a fine powder to pass through a 30-mesh sieve. The dry matter content was calculated using the following equation: DW $(\%)=(\mathrm{DW} / \mathrm{FW}) \mathrm{X} 100$.
The Kjeldahl method was used to determine $\mathrm{N}$ concentration (Jones, 1991). Tissue boron (B) concentration was determined by dry ashing $0.5 \mathrm{~g}$ of dry plant material in a muffle furnace at $500^{\circ} \mathrm{C}$ for $6 \mathrm{~h}$. The ash was dissolved in $0.1 \mathrm{~N} \mathrm{HCl}$ and $\mathrm{B}$ was determined colorimetrically $(420 \mathrm{~nm})$ with the Azomethine- $\mathrm{H}$ method (Bingham, 1982). Analyses for P, K, Ca, Mg, Fe, Mn and $\mathrm{Zn}$ were conducted by dry ashing of plant material as above. Following, the ash was dissolved in $3 \mathrm{ml} 6 \mathrm{~N} \mathrm{HCl}$ and each solution was diluted (16fold) with deionised water. Phosphorus concentration was determined using the vanado-molybdo-phosphate yellow colour method (Page et al., 1982) and K, Ca, $\mathrm{Mg}, \mathrm{Fe}, \mathrm{Mn}$ and $\mathrm{Zn}$ concentrations were determined using atomic absorption spectroscopy (Perkin-Elmer 2380, Waltham, MA, USA), using standard methods. Chloride $(\mathrm{Cl})$ was determined by titration with 0.0141 $\mathrm{N} \mathrm{AgNO}_{3}$.

\subsection{Data analysis}

The experimental layout was a randomized complete block design with one cultivar, ten treatments, four replicates per treatment and three foliar sprays. The data were subjected to analysis of variance (ANOVA) using the SPSS (17.0 for Windows) statistical package (SPSS, Inc., Chicago, Illinois). For mean comparison, the Duncan's multiple range test at $p \leq 0.05$ was used.

\section{Results}

\subsection{Plant growth parameters}

The analysis of variance for the FW and DW of whole plants showed that they were unaffected by salt type, number of sprays or $\mathrm{K}$ concentration (Tables 2 and $3)$. The maximum and minimum $\mathrm{FW}$ of new leaves were found in the KC1-1 (35.09 g) and KN3-3 (10.75 g) treatments, respectively, whereas the respective values for old leaves were found in the KN2-2 (29.51 g) and C-3 (12.19 g) treatments. Also, the maximum and minimum DW of new leaves were found in the 
(78.92 g) and KN3-3 (33.37 g) treatment, respectively, while the respective values for DW were found in the KS3-1 (29.43 g) and C-3 (16.29 g) treatments. On the other hand, dry matter percentage was significantly increased in the plants treated with one, two or three foliar applications with $\mathrm{K}_{2} \mathrm{SO}_{4}$. In detail, the maximum and minimum dry matter percentages were found in the KS2-1 (56.99\%) and KC2-3 (43.29\%) treatments, respectively.

\subsection{Concentration of macroelements in tissues}

All macro elements at the initiation of the experiment were at sufficient level, as shown by the analysis performed and according to Therios (2009). Overall, analysis of variance (ANOVA) showed that the factor 'salt type' significantly affected leaf $\mathrm{N}$ concentration (Table 3). That is, the application of $\mathrm{K}_{2} \mathrm{SO}_{4}$ led to a significantly higher $\mathrm{N}$ concentration in leaves than that of $\mathrm{KCl}$ (Figure 1). In contrast, spray application frequency and $\mathrm{K}$ concentration of salts did not affect leaf $\mathrm{N}$ concentration. The highest and lowest $\mathrm{N}$ concentration in new leaves were found in the $\mathrm{KC} 1$ $1(2.74 \%)$ and $\mathrm{C}-1$ (1.91\%) treatments, respectively, whereas the respective values in old leaves were found in the KN3-3 (2.07\%) and KS1-2 (1.59\%) treatments.

In the treatment with one foliar spray, new leaf $\mathrm{P}$ concentration increased significantly in all plants treated with K-salts; however in the treatments with two sprays, $\mathrm{P}$ concentration decreased compared to control (data not shown). Minimum and maximum $\mathrm{P}$ concentrations of new leaves were observed in the $\mathrm{C}-1$ $(0.11 \%)$ and $\mathrm{KS} 1-1 / \mathrm{C}-2(0.26 \%)$ treatments. A similar trend was observed for the $\mathrm{P}$ concentration of old leaves in the treatments with $\mathrm{K}_{2} \mathrm{SO}_{4}$. The maximum and minimum $\mathrm{P}$ concentrations of old leaves were observed in the KS2-1 (0.19\%) and KC3-3/ KS3-3 $(0.07 \%)$ treatments, respectively. In the stems of plants treated with one foliar spray, $\mathrm{P}$ concentration differed significantly with K-salt type and concentration. In contrast, the $\mathrm{P}$ concentration of plants sprayed twice was not affected by salt concentration, while in the treatments with three sprays there were no significant differences regarding salt-type or concentration. The maximum and minimum $\mathrm{P}$ concentrations in stems were observed in the KS2-2 $(0.117 \%)$ and C-1 $(0.045 \%)$ treatments, respectively. In roots, $\mathrm{P}$ concentration was not affected by salt concentration but varied with salt types in the one spray treatments. The maximum and minimum root $\mathrm{P}$ concentrations were observed in the KN2-3 (0.102\%) and C-1 $(0.032 \%)$ treatments, respectively. Concerning whole plants, salt type, number of sprays and $\mathrm{K}$ concentration of salts did not significantly affect the $\mathrm{P}$ content of plants (data not shown).

NewleafKcontentofplants treated withonefoliarspraywas significantly increased in most salt treatments compared to the control (Figure 1, Table 3). The maximum and minimum $\mathrm{K}$ concentrations were observed in the $\mathrm{KC} 3-$ $3(2.10 \%)$ and $\mathrm{C}-1(0.97 \%)$ treatments, respectively. On the other hand, the $\mathrm{K}$ concentration of old leaves was significantly increased by $\mathrm{KCl}$ applications, mainly by two or three foliar sprays. The maximum and minimum $\mathrm{K}$ concentrations were observed in $\mathrm{KC} 3-$ $3(1.39 \%)$ and $\mathrm{C}-1$ ( $0.37 \%)$ treatments, respectively. In the stems of 'Chondrolia Chalkidikis', K concentration was significantly affected by one or three spray applications with K-salts. The maximum and minimum $\mathrm{K}$ concentrations were observed in $\mathrm{KC} 3-3$ (1.22\%) and C-1 $(0.43 \%)$ treatments, respectively. In roots, there was no consistent trend in the effect of applications with $\mathrm{K}$-salts on $\mathrm{K}$ concentration. The maximum and minimum $\mathrm{K}$ concentrations were observed in $\mathrm{KS} 3$ $3(0.65 \%)$ and $\mathrm{C}-1(0.38 \%)$ treatments, respectively. According to ANOVA, $\mathrm{K}$ concentration of the plants in the study was significantly affected by salt type, number of sprays and $\mathrm{K}$ concentration of salts (Table 3 ). Namely, K-salts increased the $\mathrm{K}$ concentration in plants in the following order: $\mathrm{KCl}>\mathrm{KNO}_{3}>\mathrm{K}_{2} \mathrm{SO}_{4}$ and three foliar applications were significantly more efficient than one application. In general, Ca concentration in leaves, stems and roots of plants was not affected by the K-salt treatments. This was supported by the ANOVA results which showed that there was no significant effect of salt type, number of sprays or $\mathrm{K}$ concentration of salts on whole plant $\mathrm{Ca}$ content (Table 3). 
The maximum and minimum $\mathrm{Ca}$ concentrations of new leaves were observed in the KS2-3 (1.06\%) and KN2-2 $(0.63 \%)$ treatments, respectively, whereas the respective values in old leaves were found in the KS2-1 (3.04\%) and KS2-3 (2.08\%) treatments. On the other hand, the maximum and minimum $\mathrm{Ca}$ concentrations in stems were observed in the KC3-1 (1.32\%) and KC2-1 $(0.98 \%)$ treatments, respectively, whereas the respective values in roots were recorded in $\mathrm{KC} 1-3(0.92 \%)$ and C-3 $(0.66 \%)$ treatments. At the end of the experiment, neither the K-salts or the number of spray applications affected $\mathrm{Mg}$ concentration in leaves, stems and roots, as was also indicated by ANOVA for whole plants (Table 3). The maximum $\mathrm{Mg}$ concentration of new and old leaves, stems and roots was observed in the KN3-3 $(0.22 \%), \mathrm{C}-3$ $(0.42 \%), \mathrm{KN} 3-2(0.27 \%)$ and KN1-1/ KN2-1 (0.52\%) treatments, respectively. On the other hand, the respective minimum values were found in the treatments $\mathrm{KC2}-1 /$ KS2-1/ KC2-2/ KS3-3 (0.17\%), KC1-2 (0.30\%), C1-1/ KC2-1 (0.16\%) and KS2-3 (0.38\%) (data not shown).

Table 2. Fresh and dry weight of new leaves, old leaves and roots and dry matter (\%) of olive (Olea europaea L.) cv. Chondrolia Chalkidikis at the end of the experiment (108 days).

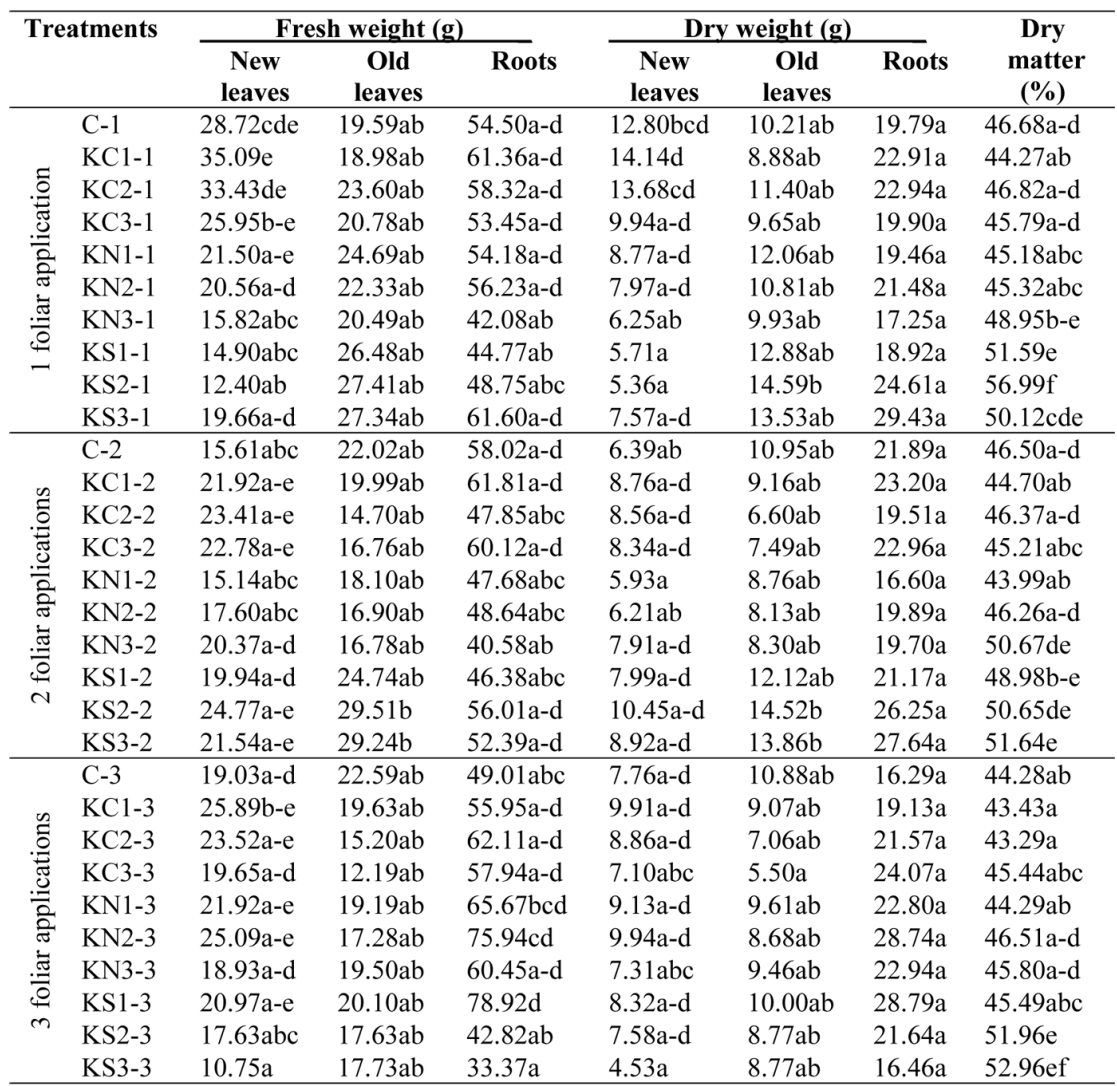

Means with different letters in the same column are significantly different for $p \leq 0.05(\mathrm{n}=30)$. Control=C-1, C-2 and C-3. KCl $2 \%=\mathrm{KC} 1-1, \mathrm{KC} 1-2, \mathrm{KC} 1-3 ; \mathrm{KCl} 4 \%=\mathrm{KC} 2-1, \mathrm{KC} 2-2, \mathrm{KC} 2-3$; KCl 6\%=KC3-1, KC3-2, KC3-3. KNO $2.7 \%=\mathrm{KN} 1-1, \mathrm{KN} 1-2$, $\mathrm{KN} 1-3 ; \mathrm{KNO}_{3} 5.4 \%=\mathrm{KN} 2-1, \mathrm{KN} 2-2, \mathrm{KN}_{2}-3 ; \mathrm{KNO}_{3} 8.1 \%=\mathrm{KN} 3-1, \mathrm{KN} 3-2, \mathrm{KN} 3-3 . \mathrm{K}_{2} \mathrm{SO}_{4} 2.3 \%=\mathrm{KS} 1-1, \mathrm{KS} 1-2, \mathrm{KS}_{1}-3 ; \mathrm{K}_{2} \mathrm{SO}_{4}$ $4.6 \%=\mathrm{KS} 2-1, \mathrm{KS} 2-2, \mathrm{KS} 2-3 ; \mathrm{K}_{2} \mathrm{SO}_{4} 6.9 \%=\mathrm{KS} 3-1, \mathrm{KS} 3-2, \mathrm{KS} 3-3$ 
Table 3. P-values of the two-way ANOVA for the variables salt type, number of sprays and K concentration of salts. Weight and nutrient concentrations (except $\mathrm{N}$ ) concern whole plants.

\begin{tabular}{llll}
\hline & \multicolumn{1}{c}{ Salt type } & \multicolumn{1}{c}{$\begin{array}{c}\text { Number of } \\
\text { sprays }\end{array}$} & \multicolumn{1}{c}{$\begin{array}{c}\text { K } \\
\text { concentration }\end{array}$} \\
\hline Fresh weight & $0.627 \mathrm{~ns}^{1}$ & $0.519 \mathrm{~ns}$ & $0.737 \mathrm{~ns}$ \\
Dry weight & $0.362 \mathrm{~ns}$ & $0.416 \mathrm{~ns}$ & $0.697 \mathrm{~ns}$ \\
Leaf N & $0.009^{* *}$ & $0.412 \mathrm{~ns}$ & $0.474 \mathrm{~ns}$ \\
$\mathrm{P}$ & $0.123 \mathrm{~ns}$ & $0.069 \mathrm{~ns}$ & $0.694 \mathrm{~ns}$ \\
$\mathrm{~K}$ & $<0.001^{* * *}$ & $0.005^{* *}$ & $<0.001^{* * *}$ \\
$\mathrm{Ca}$ & $0.975 \mathrm{~ns}$ & $0.267 \mathrm{~ns}$ & $0.950 \mathrm{~ns}$ \\
$\mathrm{Mg}$ & $0.885 \mathrm{~ns}$ & $0.670 \mathrm{~ns}$ & $0.962 \mathrm{~ns}$ \\
$\mathrm{Mn}$ & $0.727 \mathrm{~ns}$ & $0.290 \mathrm{~ns}$ & $0.805 \mathrm{~ns}$ \\
$\mathrm{Zn}$ & $0.115 \mathrm{~ns}$ & $<0.001^{* * *}$ & $0.247 \mathrm{~ns}$ \\
$\mathrm{~B}$ & $0.143 \mathrm{~ns}$ & $0.148 \mathrm{~ns}$ & $0.606 \mathrm{~ns}$ \\
$\mathrm{Fe}$ & $0.643 \mathrm{~ns}$ & $0.034^{*}$ & $0.812 \mathrm{~ns}$ \\
$\mathrm{Cl}$ & $<0.001^{* * *}$ & $<0.001^{* * *}$ & $<0.001^{* * *}$ \\
\hline
\end{tabular}

${ }^{1}$ Non significant. *Significance for $p<0.05$. **Significance for $p<0.01$. ***Significance for $p<0.001$.

\subsection{Concentration of microelements in tissues}

At the initiation of the experiment, there was a relatively deficient range level in leaf $\mathrm{Mn}$ concentration (Therios, 2009). At the end of this study, although Mn increased slightly, it was still below sufficiency level. In general, Mn concentration in leaves, stems and roots was unaffected by salt treatments or spray application frequency and this is also shown by the results of ANOVA (Table 3). The maximum Mn concentration in new and old leaves, stems and roots were observed in the treatments KS2-3 $(36 \mu \mathrm{g} / \mathrm{g}), \mathrm{KC} 2-1(52 \mu \mathrm{g} / \mathrm{g})$, KS3-3 $(14 \mu \mathrm{g} / \mathrm{g})$ and $\mathrm{KS} 3-3(101 \mu \mathrm{g} / \mathrm{g})$, respectively, whereas the respective minimum values were found in the treatments KS2-1 (18 $\mu \mathrm{g} / \mathrm{g}), \mathrm{KS} 3-1(30 \mu \mathrm{g} / \mathrm{g}), \mathrm{KN} 2-$ $3(7 \mu \mathrm{g} / \mathrm{g})$ and $\mathrm{KN} 3-2(49 \mu \mathrm{g} / \mathrm{g})$ (data not shown).

Before the application of $\mathrm{K}$ foliar sprays, there was a sufficient range level of $\mathrm{Zn}$ concentrations in leaves
(Therios, 2009). In new leaves, $\mathrm{Zn}$ concentration did not present any significant difference as a result of salt treatments (Table 3). The maximum and minimum $\mathrm{Zn}$ concentrations were observed in the KC2-2 (29 $\mu \mathrm{g} / \mathrm{g})$ and $\mathrm{KS} 2-3(16 \mu \mathrm{g} / \mathrm{g})$ treatments, respectively (Figure 2). On the other hand, $\mathrm{Zn}$ concentration of old leaves was reduced in all salt treatments and spray application frequencies compared to the control (C-1). The maximum and minimum $\mathrm{Zn}$ concentrations were observed in the C-1 $(34 \mu \mathrm{g} / \mathrm{g})$ and KS2-3 $(13 \mu \mathrm{g} / \mathrm{g})$ treatments, respectively. Similarly, the highest $\mathrm{Zn}$ concentration in stems was that of the control (C-1), but did not significantly differ than most treatments. The maximum and minimum $\mathrm{Zn}$ concentrations of stems were observed in the C-1 $(15 \mu \mathrm{g} / \mathrm{g})$ and C-3 $(6 \mu \mathrm{g} / \mathrm{g})$ treatments, which were the controls of one and three foliar application treatments, respectively. Zinc concentration in roots did not present significant differences to the control or among salt treatments. 

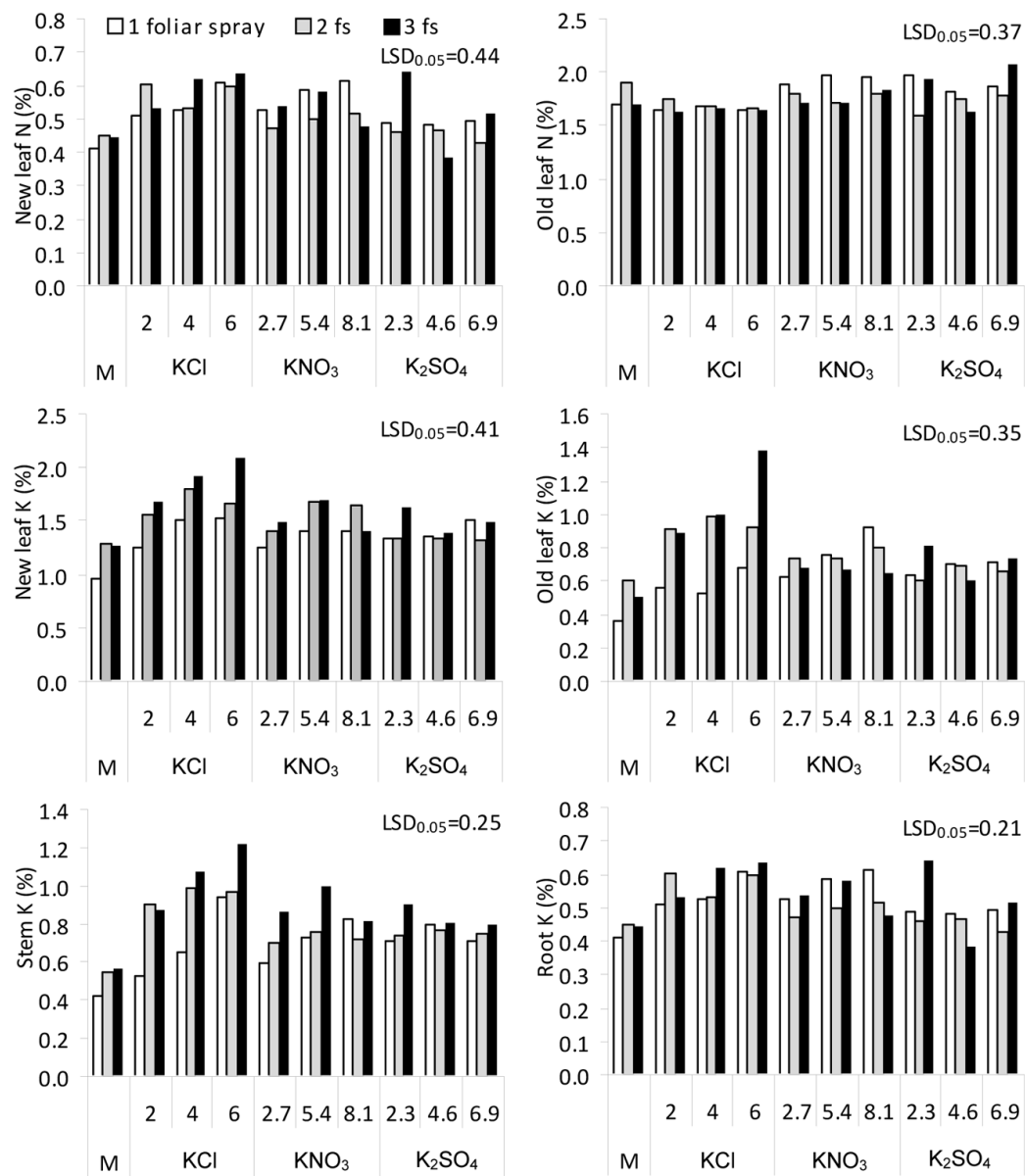

Figure 1. Nitrogen concentrations in new and old leaves, and potassium concentrations in new leaves, old leaves, stems and roots of olive (Olea europaea L.) cv. Chondrolia Chalkidikis at the end of the experiment (108 days). Control is indicated with ' $\mathrm{M}$ ' and salt concentrations in treatments are expressed as percent (\%) w/v.

The maximum and minimum $\mathrm{Zn}$ concentrations were observed in the KS3-2 (18 $\mu \mathrm{g} / \mathrm{g})$ and KN3-2 $(10 \mu \mathrm{g} / \mathrm{g})$ treatments, respectively. Finally, irrespective of plant parts, spray application frequency significantly affected $\mathrm{Zn}$ concentration in the plants of the study (Table 3). More specifically, one foliar spray with K-salts had more favourable results on the $\mathrm{Zn}$ concentration of whole plants than two or three sprays. Analysis of leaves at the beginning of the treatments showed that there was a sufficient range level in B concentration (Therios, 2009). Boron concentration in the leaves of the control plants did not differ significantly from that of the salttreated plants (Table 3). The maximum and minimum $\mathrm{B}$ concentrations of new leaves were observed in the KN3-1 $(24 \mu \mathrm{g} / \mathrm{g})$ and $\mathrm{KN} 3-2(12 \mu \mathrm{g} / \mathrm{g})$ treatments, respectively, whereas the respective values for old leaves were observed in the KS1-2 (27 $\mu \mathrm{g} / \mathrm{g})$ and C-1 $(17 \mu \mathrm{g} / \mathrm{g})$ treatments (data not shown). 

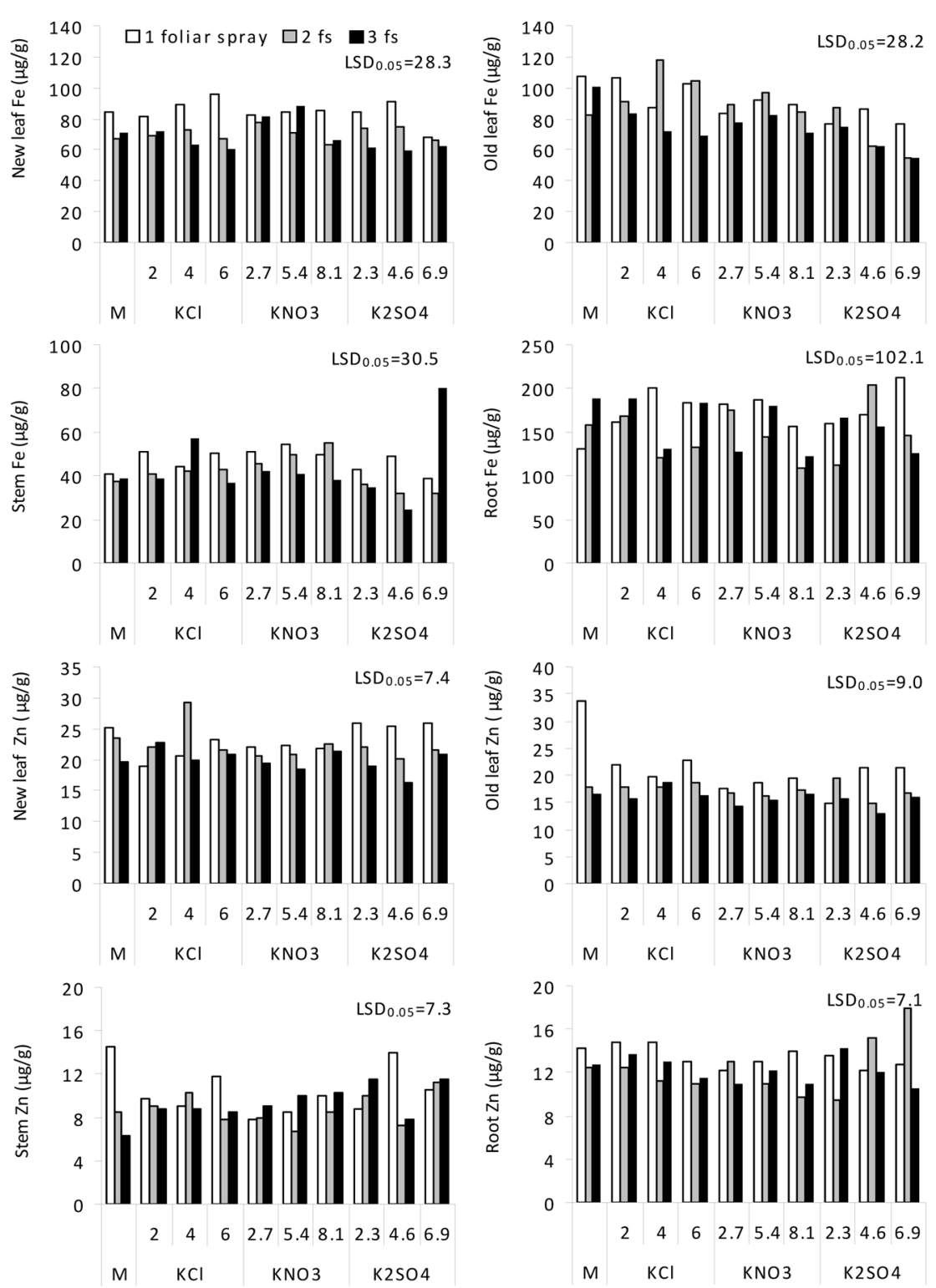

Figure 2. Iron and zinc concentrations in new leaves, old leaves, stems and roots of olive (Olea europaea L.) cv. Chondrolia Chalkidikis at the end of the experiment (108 days). Control is indicated with ' $M$ ' and salt concentrations in treatments are expressed as percent $(\%) \mathrm{w} / \mathrm{v}$. 
Boron concentration of stems was found to be slightly, but not significantly, increased after the $3^{\text {rd }}$ foliar application of salts. The maximum and minimum $\mathrm{B}$ concentrations in stems were observed in the $\mathrm{KC} 1-3$ $(21 \mu \mathrm{g} / \mathrm{g})$ and $\mathrm{KN} 3-1(12 \mu \mathrm{g} / \mathrm{g})$ treatments, respectively. Similarly, regarding B concentration in roots, no significant variation was observed with different salts and their application frequency. The maximum and minimum B concentrations in roots were observed in the KN1-2/ KS3-2 $(25 \mu \mathrm{g} / \mathrm{g})$ and KN3-2 $(19 \mu \mathrm{g} / \mathrm{g})$ treatments, respectively. Overall, ANOVA showed that salt type, number of foliar applications and $\mathrm{K}$ concentration of salts did not significantly affect B concentration (Table 3).

At the initiation of this study, olive plants were found to be Fe-sufficient (Therios, 2009). At the end of the experiment, Fe concentration of all plant parts did not vary significantly compared to the control (Figure 2). Only in old leaves did the application of K-salts lead to a significant decrease in $\mathrm{Fe}$ concentration compared to the control. ANOVA revealed that spray application frequency had a significant effect on Fe content of olive plants (Table 3). More specifically, one-spray treatment gave significantly better results than two or three sprays. The maximum and minimum $\mathrm{Fe}$ concentrations in new leaves were observed in the KC3-1 $(96 \mu \mathrm{g} / \mathrm{g})$ and $\mathrm{KS} 2-3(60 \mu \mathrm{g} / \mathrm{g})$ treatments, respectively, whereas the respective values for old leaves were found in the $\mathrm{KC2}$ $2(118 \mu \mathrm{g} / \mathrm{g})$ and $\mathrm{KS} 3-3(55 \mu \mathrm{g} / \mathrm{g})$ treatments. Moreover, the maximum and minimum $\mathrm{Fe}$ concentrations in stems were observed in the KS3-3 (80 $\mu \mathrm{g} / \mathrm{g})$ and KS2$3(24 \mu \mathrm{g} / \mathrm{g})$ treatments, respectively. Finally, in roots, the maximum and minimum $\mathrm{Fe}$ concentrations were observed in the KS3-1 $(213 \mu \mathrm{g} / \mathrm{g})$ and KN3-2 $(108 \mu \mathrm{g} / \mathrm{g})$ treatments, respectively.

Most of plants treated with $\mathrm{KCl}$ presented significantly higher leaf $\mathrm{Cl}$ concentration than the control (Figure 3). The maximum and minimum $\mathrm{Cl}$ concentrations of new leaves were observed in the KC3-3 (0.967\%) and C-1 (0.026\%) treatments, respectively. On the other hand, the maximum and minimum $\mathrm{Cl}$ concentrations in old leaves were observed in the KC3-3 (1.17\%) and $\mathrm{KN} 2-1 \quad(0.015 \%)$ treatments, respectively. In stems, $\mathrm{Cl}$ concentration was not significantly affected by the K-salt treatments compared to the control in the one-spray application. However, after the $2^{\text {nd }}$ and $3^{\text {rd }}$ spray application, there was a significant increase in the $\mathrm{Cl}$ concentration in stems in comparison to the other treatments. The maximum and minimum $\mathrm{Cl}$ concentrations were observed in the KC3-3 (0.470\%) and KS1-3 (0.005\%) treatments, respectively. Regarding the $\mathrm{Cl}$ concentration in roots, it was not affected by any of the treatments and by none of the foliar application frequencies. The maximum and minimum $\mathrm{Cl}$ concentrations of roots were observed in the $\mathrm{KC} 2-2(0.672 \%)$ and $\mathrm{KS} 3-3(0.030 \%)$ treatments, respectively. Generally, $\mathrm{Cl}$ concentration in olive plants was significantly affected by salt type, number of foliar applications and $\mathrm{K}$ content of salts (Table 3). As expected, $\mathrm{KCl}$ treatments led to the highest $\mathrm{Cl}$ concentrations, about four times higher than in the $\mathrm{KNO}_{3}$ and $\mathrm{K}_{2} \mathrm{SO}_{4}$ treatments. Also, three sprays with $\mathrm{K}$-salts led to higher $\mathrm{Cl}$ concentrations than the twospray treatments and the latter gave better results than the one-spray treatments. Moreover, the efficiency of the $\mathrm{K}$ content (in $\% \mathrm{w} / \mathrm{v}$ ) of salts on the $\mathrm{Cl}$ concentration of plants followed the order $3>2>1>$ control.

\section{Discussion}

It is clear that the foliar application of the K-salts studied at different concentrations and frequencies had no significant effect on the FW and DW of the different plant parts of the olive cultivar 'Chondrolia Chalkidikis'. This is in line with the results of Restrepo-Diaz et al. (2009) experimenting on olive, although they applied $\mathrm{KCl}$ at concentrations higher than 4\%. In agreement with our findings, Ben Mimoun et al. (2004) suggested that no effect of the $\mathrm{KNO}_{3}$ treatments was observed on the vegetative growth of olive. The lack of significant effects on the biomass of soybeans treated with high rates of foliar $\mathrm{K}$ fertilizer has been also reported (Mallarino and UIHaq, 1998). 

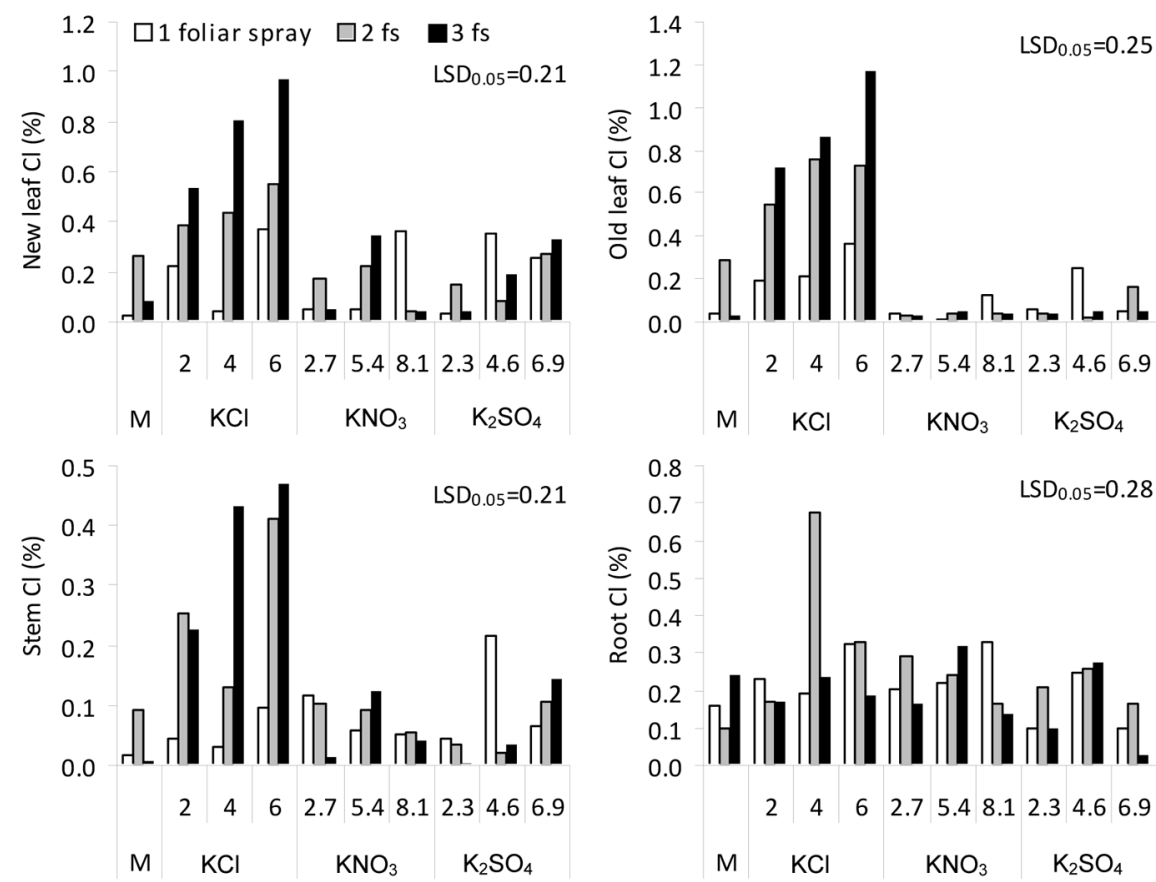

Figure 3. Chloride concentrations (\%) in new leaves, old leaves, stems and roots of olive (Olea europaea L.) cv. Chondrolia Chalkidikis at the end of the experiment (108 days). Control is indicated with ' $\mathrm{M}$ ' and salt concentrations in treatments are expressed as percent $(\%) \mathrm{w} / \mathrm{v}$.

Potassium as a highly phloem mobile element (Marschner, 2002) can move from organs of relative abundance to growing tissues so that plants do not immediately exhibit $\mathrm{K}$ deficiency or depressed plant growth when the demand for the particular nutrient is higher than its uptake rate (Fernandez et al., 2013). On the other hand, in the present study, it appears that in comparison to the control, the dry matter percentage was significantly increased only in the treatments with $\mathrm{K}_{2} \mathrm{SO}_{4}$. Similar results were found in foliar treatments with $\mathrm{K}_{2} \mathrm{SO}_{4}$ which improved the shoot $\mathrm{FW}$ of sunflower (Saeed Akram et al., 2009). This may be due to the beneficial effect of sulphate in enhancing dry matter percentage. Our findings showed that there was an increase in $\mathrm{N}$ concentration in both new and old leaves with one application of different concentrations of $\mathrm{KNO}_{3}$ compared to the control. However, $\mathrm{N}$ concentration was not affected after two and three applications of K-salts. Similar conclusions for olive (i.e. that $\mathrm{N}$ was not significantly influenced by $\mathrm{K}$ concentration) have been also reported by other researchers (Saykhul et al., 2013). In our case, however, leaf $\mathrm{N}$ concentration increased significantly by about $30 \%$ with $\mathrm{KNO}_{3}$ compared to the other K salts.

Regarding P, our results suggested that its concentration was affected by some K-salt treatments with one or two spray applications, but the trend was not consistent. In agreement to these findings, Veberic et al. (2005) experimenting with apple cv. Golden Delicious reported that foliar application of $\mathrm{K}$ fertilizers led to minor changes of leaf $\mathrm{P}$ concentration. 
As regards $\mathrm{K}$ concentration of the new leaves of the control plants it never reached deficiency level $(<0.50 \%$; Therios, 2009) throughout the study. On the other hand, there was a significant increase in the $\mathrm{K}$ concentration of different parts of the olive plant with all $\mathrm{K}$ salts and spray frequency in the present study compared to the control. Restrepo-Diaz et al. (2009) have also reported a significant interaction between the number of foliar applications and leaf $\mathrm{K}$ concentration of olive plants. Namely, they suggested that foliar applications with $\mathrm{KCl}, \mathrm{KNO}_{3}, \mathrm{~K}_{2} \mathrm{SO}_{4}, \mathrm{KH}_{2} \mathrm{PO}_{4}$ and $\mathrm{K}_{2} \mathrm{CO}_{3}$ are effective in increasing leaf $\mathrm{K}$ concentration in olive leaves and that two foliar applications of $\mathrm{KCl}$ $(0.05$ or $2.50 \mathrm{mM})$ were enough to increase leaf $\mathrm{K}$ concentrations. In our study, although $\mathrm{KCl}$ applications were effective in increasing $\mathrm{K}$ content in olive plants when grown in a K-deficient medium, they were not effective when plants were adequately fertilized. These findings are supported by a number of different studies. Zeng et al. (2001) had similar results in pistachio. Sotiropoulos et al. (2010) also reported that foliar application of agriphos, chelan-K, silene-K, and $\mathrm{KNO}_{3}$ resulted in an increase in leaf $\mathrm{K}$ concentration of the peach (Prunus persica (L.) Batsch), for three consecutive years of experimentation. Shafer and Reed (1986) who evaluated the K absorption of several K sources of soybean (Glycine max L.) excised leaves found that $\mathrm{KNO}_{3}, \mathrm{~K}_{2} \mathrm{CO}_{3}$ and a few phosphate forms were very promising. It has also been reported that $\mathrm{KCl}$ was very effective in enhancing $\mathrm{K}$ concentration of groundnut (Arachis hypogaea L.) leaves when applied foliarly (Umar et al., 1999). Furthermore, similar findings were observed in cotton, where a greater increase in leaf $\mathrm{K}$ concentration resulted from the foliar application of $\mathrm{KC} 1$ than $\mathrm{K}_{2} \mathrm{SO}_{4}$ (Chang and Oosterhuis, 1995). The greater effectiveness of $\mathrm{KCl}$ compared to the two other K-salts may be attributed to its lower point of deliquescence (POD; Schönherr, 2002). The latter is defined as the relative humidity (RH) value at which the salt becomes a solute. Thereby, the lower the POD of a salt, the sooner it will dissolve upon exposure to ambient $\mathrm{RH}$ and penetrate cuticle (Fernandez et al., 2013). Accordingly, in our study, the lower the POD value of a salt, the higher its efficiency to supply plants with $\mathrm{K}$.

Furthermore, in the present study it was found that there was no significant variation in $\mathrm{Ca}$ and $\mathrm{Mg}$ concentrations in different plant parts among the control and K treatments. Similarly, Saykhul et al. (2013) experimenting with three olive cultivars under hydroponic culture, reported that leaf $\mathrm{Ca}$ and $\mathrm{Mg}$ concentrations were not - in most cases - influenced by $\mathrm{K}$ treatments.

In addition, we found that the micronutrient concentrations in different parts of the plants were, likewise, not significantly affected by $\mathrm{K}$ treatments. This is in agreement with the findings of Sotiropoulos et al. (2010) who reported that in the peach cv. Andross $\mathrm{Fe}, \mathrm{Mn}$, and $\mathrm{Zn}$ concentrations of leaves were not affected by the foliar sprays with different K-containing fertilizers. The observation that two or three sprays with $\mathrm{K}$ led to lower Fe concentration compared to one spray may be attributed to the 'dilution effect' due to close relation between cell extension and $\mathrm{K}$ content. In detail, cell extension is the consequence of the accumulation in the cells of $\mathrm{K}+$, which is required for both stabilizing the $\mathrm{pH}$ in the cytoplasm and increasing the osmotic potential in the vacuoles (Marschner, 2002). Moreover, in accordance to our results, B concentration in cotton was not affected by preplant application of $112 \mathrm{~kg} \mathrm{~K}$ ha $^{-1}$ (Pettigrew and Meredith, 1997).

On the other hand, our results showed that, compared to the control, $\mathrm{Cl}$ concentration significantly increased with the $\mathrm{KCl}$ foliar sprays. This may be due to the higher solubility of $\mathrm{KCl}$ resulting in greater availability of free $\mathrm{Cl}$ - and better penetration through leaf cuticles. However, it was found that in all cases the leaf $\mathrm{Cl}$ concentration did not exceed the toxicity threshold level of $0.5 \% \mathrm{DW}$. This indicates that the use of $\mathrm{KCl}$ on young olive plants does not cause toxicity problems as a result of high concentrations of Cl- (Restrepo-Diaz et al., 2009). Similar findings were reported in pistachio (Zeng et al., 2001), whereas the opposite was observed in citrus which are very sensitive to Cl- toxicity (Maas, 1993). 
Finally, comparing different $\mathrm{K}$ salts, Schönherr and Luber (2001) reported that $\mathrm{KCl}$ and $\mathrm{K}_{2} \mathrm{CO}_{3}$ were the most appropriate $\mathrm{K}$-salts for foliar fertilization because of their high solubility and good penetration through leaf cuticles. The application of high concentrations of $\mathrm{K}$ may, however, cause leaf injuries or leaf burning (not observed in our case) with a subsequent reduction in leaf $\mathrm{K}$ accumulation (Marschner, 2002). The reduction in nutrient absorption through the leaves that we observed in some cases may have been due to destruction of ectodesmata structures. This is further supported by Weinbaum (1988), who reported that leaf burning, which is a common problem of foliar spraying at high concentrations can be avoided with the use of low salt index fertilizers (i.e. those that are free of $\mathrm{Na}$ and $\mathrm{Cl}$ ), containing low $\mathrm{K}$ and a proper adjuvant. Moreover, phytotoxicity problems were not observed by any of the foliar $\mathrm{K}$ sources or concentrations when the $\mathrm{pH}$ levels of the spray solutions ranged from 6.5 to 7.7 (Jifon and Lester, 2009).

\section{Conclusions}

Our results suggest that foliar $\mathrm{K}$ uptake can be regulated by selecting an appropriate K-salt which will be sprayed at an adequate number of times. With the exception of $\mathrm{K}$ and $\mathrm{Cl}$, spray applications of $\mathrm{KCl}$, $\mathrm{KNO}_{3}$ or $\mathrm{K}_{2} \mathrm{SO}_{4}$ do not seem to alter significantly the nutritional status of olive plants. Obviously, the $\mathrm{K}$ status of the olive cultivar 'Chondrolia Chalkidikis' could be better improved by applying foliarly $\mathrm{KCl}$ than $\mathrm{KNO}_{3}$ or $\mathrm{K}_{2} \mathrm{SO}_{4}$, but $\mathrm{Cl}$ concentration in leaves should be kept below toxic levels. The results of our short-term study suggest that foliar fertilization with $\mathrm{K}$ should merely be used as a supplemental fertilization method, taking into consideration some limitations. Further studies with olive trees in the field are proposed, in order to reach sound conclusions, since there are numerous outdoor factors that influence fertilizer efficiency.

\section{Acknowledgements}

The first author would like to thank the Greek State Scholarship's Foundation (IKY) for supporting this work.

\section{References}

Ben Mimoun, M., Loumi, O., Ghrab, M., Latiri, K., Hellali, R. 2004. Foliar potassium application on olive tree. IPI Regional Workshop on Potassium and Fertigation Development in West Asia and North Africa; Rabat, Morocco.

Bingham, F.T. 1982. Boron. In: A.L. Page, R.H. Miller, D.R. Keeney (eds.). Methods of Soil Analysis. Part 2. Chemical and Microbiological Properties. American Society of Agronomy, Madison, WI, pp: 431-448.

Brady, N.C., Weil, R.R. 2002. The Nature and Properties of Soils, 13th Edition. Prentice Hall, Upper Saddle River, N.J., U.S.A.

Chang, M.A., Oosterhuis, M.D. 1995. Cotton response to foliar application of potassium compounds at different $\mathrm{pH}$ levels. Better Crops. $79,20-22$.

Dikmelik, U., Puskulcu, G., Altug, M., Irget, E. M. 2000. The effect of $\mathrm{KNO}_{3}$ application on the yield and fruit quality of olive. In: D. Anac, P. Martin Prevel (eds.). Improved Crop Quality by Nutrient Management. Kluwer Academic Publishers, Dordrecht, The Netherlands, pp: 77-80.

Elloumi, O., Ghrab, M., Ben Mimoun, M. 2009. Responses of olive trees (cv. Chemlali) after five years of experiment to potassium mineral nutrition under rainfed condition. The Proceedings of the International Plant Nutrition Colloquium XVI, UC Davis. http://escholarship. org/uc/item/2zb9p060. 
Fernandez, V., Sotiropoulos, T., Brown, P. 2013. Foliar Fertilization: Scientific Principles and Field Practices. International Fertilizer Industry Association, Paris, France, 140 p.

Fernandez-Escobar, R. 2004. Fertilization. In: Olive Cultivation. D. Barranco, R. Fernandez-Escobar, R. Rallo (eds.). Mundi-Prensa, Madrid, Spain, pp: 287-320.

Fernandez-Escobar, R., Moreno, R., Garcia Creus, M. 1999. Seasonal changes of mineral nutrients in olive leaves during the alternate-bearing cycle. Sci. Hortic. 82, 25-45.

Girma, K., Martin, L.K., Freeman, W.K., Mosali, J., Teal, K.R., Raun, R.W., Moges, M.S., Amall, B.D. 2007. Determination of optimum rate and growth for foliar applied phosphorus in corn. Comm. Soil Sci. Plant Anal. 38, 1137-1154.

Jifon, J.L., Lester, G.E. 2009. Foliar potassium fertilization improves fruit quality of field-grown muskmelon on calcareous soils in south Texas. J. Sci. Food Agric. 89, 2452-2460.

Jones, J.B.Jr. 1991. Kjeldahl Method for Nitrogen Determination. Micro-Macro Publishing, Athens, Georgia, USA, pp: 3-20.

Khemira, K., Righetti, T.L. Azarenko, A.N. 1999. Distribution of urea-deprived nitrogen supplied to apple leaves. HortScience. 34, 1079-1081.

Maas, E.V. 1993. Salinity and citriculture. Tree Physiol. 12, 195-216.

Mallarino, A.P., Ul-Haq, M. 1998. What about foliar fertilization of soybean?. Fluid J. 31, 8-11.

Marschner, H. 2002. Mineral Nutrition of Higher Plants. Academic Press, San Diego, CA.

Mengel, K., Kirkby, E.A. 2001. Principles of Plant Nutrition, Fifth Edition. Kluwer Academic
Publishers, Dordrecht, The Netherlands, 849 p.

Page, A. L., Miller, H. R., Keeney, R. D. 1982. Chemical and microbiological properties. In: Methods of Soil Analysis, Vol. 2. Soil Science Society of America, Madison, WI, 1159 p.

Pettigrew W. T., Meredith Jr. W. R. 1997. Dry matter production, nutrient uptake, and growth of cotton as affected by potassium fertilization, J. Plant Nutr. 20, 531-548.

Restrepo-Diaz, H., Benlloch, M., Fernandez-Escobar, R. 2009. Leaf potassium accumulation in olive plants related nutritional $\mathrm{K}$ status, leaf age and foliar application of potassium salts. J. Plant Nutr. $32,1108-1121$.

Saeed Akram, M., Ashraf, M., Akram, A.N. 2009. Effectiveness of potassium sulfate in mitigating salt-induced adverse effects on different physiobiochemical attributes in sunflower (Helianthus annuus L.). Flora (Jena) 204(6), 471-483.

Saykhul, A., Chatzistathis, T., Chatzissavvidis, C., Koundouras, S., Therios, I., Dimassi, K. 2013. Potassium utilization efficiency of three olive cultivars grown in a hydroponic system. Sci. Hort. $162,55-62$

Schönherr, J. 2002. Foliar nutrition using inorganic salts: Laws of cuticular penetration. Acta Hort. 594, 77-84.

Schönherr, J., Luber, M. 2001. Cuticular penetration of potassium salts: Effects of humidity, anions and temperature. Plant Soil 236, 117-122.

Shafer, E.W., Reed, W.D. 1986. The foliar absorption of potassium from organic and inorganic potassium carriers. J. Plant Nutr. 9(2), 143-157.

Sotiropoulos, T., Therios, I., Voulgarakis, N. 2010. Effect of various foliar sprays on some fruit quality attributes and leaf nutritional status of the peach cultivar 'Andross'. J. Plant Nutr. 33, 471-484. 
Swietlik, D., Faust, M. 1984. Foliar nutrition of fruit crops. Hort. Rev. 6, 287-355.

Therios, I.N. 2009. Olives. Crop Production Science in Horticulture. Series No 18. CAB International, Wallingford, U.K., 409 p.

Toscano, P., Godino, G., Belfiore, T., Bricolli-Bati, C. 2002. Foliar fertilization: A valid alternative for olive cultivar. Acta Hortic. 594, 191-195.

Umar, S., Bansal. K.S., Imas, P., Magen, H. 1999. Effect of foliar fertilization of potassium on yield, quality, and nutrient uptake of groundnut. J. Plant Nutr. 22(11), 1785-1795.
Veberic, R., Vodnik, D., Stampar, F. 2005. Influence of foliar-applied phosphorus and potassium on photosynthesis and transpiration of 'Golden Delicious' apple leaves (Malus domestica Borkh). Acta Agric. Slov. 85(1), 143-155.

Weinbaum, S.A. 1988. Foliar nutrition of fruit trees. In: P.M. Neumann (ed.). Plant Growth and Leaf Applied Chemicals. CRC Press Inc., Boca Raton, FL, pp: 81-100.

Zeng, Q., Brown, H.P., Holtz, A.B. 2001. Potassium fertilization affects soil $\mathrm{K}$, leaf $\mathrm{K}$ concentration and nut yield and quality of mature pistachio trees. HortScience. 36, 85-89. 